\title{
PENGGUNAAN COOPERATIVE LEARNING TIPE NUMBERED HEADS TOGETHER (NHT) UNTUK MENINGKATKAN MOTIVASI DAN PRESTASI HASIL BELAJAR SISWA SMP
}

\author{
Dandan Luhur Saraswati ${ }^{1}$ \\ Ishafit $^{2}$ \\ Pendidikan Fisika, Fakultas Teknik Matematika dan IPA, Universitas Indraprasta ${ }^{1}$ \\ Pendidikan Fisika, Fakultas Keguruan dan Ilmu Pendidikan, Universitas Ahmad \\ Dahlan $^{2}$ \\ Email: dandanluhur@gmail.com
}

\begin{abstract}
Abstrack
Physics lessons in addition considered a very frightening specter because it filled with formulas, often learning application too monotonous and boring that is by using learning CDs. It is what lies behind this action research. This study aims to decide students' motivation and achievement results for physics lesson after using cooperative learning type Numbered Heads Together (NHT).

The study was conducted in SMP Muhammadiyah Yogyakarta 9. This type of research is a classroom action research settingVIII A class totaling 40 students. learning model used is a model of cooperative learning type Numbered Heads Together (NHT). Plan 2 cycles of research conducted and completed in the second cycle. Datawere collected with a learning achievement test results, observation sheets and questionnaires. The analysis is descriptive qualitative.

Results motivation questionnaire given to each learning cycle is obtained in the first cycle is 65\% of students in both categories, $35 \%$ of students in the classical category of less and 66.3\%. In the second cycle of $80 \%$ of students in the excellent category, $20 \%$ of students in both categories and in the classical as much as $95 \%$ of students have had a very good learning motivation. Achievement of learning outcomes of students has increased significantly as the first cycle were 21 students approximately $52.5 \%$ declared complete with an average grade of 6.17, while the lowest value 4.5 and the highest value of 7.5, the second cycle of the average value of the class to 8.29 with the percentage of classical completeness $100 \%$ with the lowest value of 6.7 and the highest 10.
\end{abstract}

Keywords: Cooperative Learning, Numbered Heads Together (NHT), motivation, achievement of learning outcomes physics . 


\section{PENDAHULUAN}

Pendidikan nasional berfungsi mengembangkan kemampuan, membentuk watak dan peradaban bangsa bermartabat dalam rangka mencerdaskan kehidupan bangsa. Berdasarkan fungsi pendidikan nasional tersebut maka peran guru menjadi kunci keberhasilan dalam misi pendidikan dan pembelajaran di sekolah, selain bertanggung jawab untuk mengatur, mengarahkan, dan menciptakan suasana kondusif yang mendorong anak didik untuk melaksanakan kegiatan di kelas.

Pada kenyataannya pelajaran fisika dianggap sebagai momok yang sangat menakutkan bagi siswa karena dipenuhi dengan menghapal rumus. Selain itu, proses pembelajaran yang membosankan dan monoton yaitu yang hanya menggunakan compact disk (CD) pembelajaran. Hal inilah yang terjadi di salah satu sekolah menengah pertama (SMP) di Yogyakarta yang diketahui dari guru pengampu mata pelajaran fisika. Sehingga sering ditemukan siswa yang malas untuk mengikuti pelajaran fisika. Akibat yang ditimbulkan dari permasalahan di atas adalah rendahnya hasil prestasi belajar siswa. Ada beberapa cara yang dilakukan siswa untuk menghindari pelajaran fisika diantaranya yaitu berpura-pura sakit, kegiatan organisasi sekolah, berkali-kali ijin ke toilet, dan lain-lain.

Dalam pelajaran fisika, salah satu hal yang harus diperhatikan oleh guru dalam mengajarkan suatu pokok bahasan adalah pemilihan model pembelajaran yang sesuai dengan materi yang diajarkan karena melihat kondisi siswa yang memiliki karakteristik yang berbeda antara satu dengan yang lainnya dalam menerima materi pelajaran yang disajikan guru di kelas, ada siswa yang memiliki daya serap cepat, sedang dan adapula yang lama (Wijaya \& Dwitagama, 2008).

Wijaya \& Dwitagama (2008) menjelaskan NHT merupakan suatu metode belajar dimana setiap siswa diberi nomor kemudian dibuat suatu kelompok kemudian secara acak guru memanggil nomor dari siswa. Data prestasi hasil belajar ujian semester pelajaran fisika dengan rata-rata sebesar 4,35 yang tergolong masih sangat rendah jika dibandingkan dengan mata pelajaran lain. Penggunaan model pembelajaran ini 
akan diterapkan pada penelitian ditemukan permasalahan yang timbul tindakan kelas (PTK). Arikunto, diantaranya : (1) perhatian siswa dalam Suhardjono dan Supardi (2009) PTK pelajaran fisika masih rendah dilihat bertujuan untuk meningkatkan mutu dari sering ditemukannya siswa yang proses dan hasil pembelajaran, malas untuk mengikuti pelajaran fisika; mengatasi masalah pembelajaran, (2) partisipasi aktif siswa dalam proses meningkatkan profesionalisme dan pembelajaran dikelas masih rendah; (3) menumbuhkan budaya akademik. bagi siswa pelajaran fisika merupakan Dalam proses pelaksanaan, rencana momok yang sangat menakutkan; (4) yang telah disusun kemudian dilakukan proses pembelajaran yang monoton dan suatu observasi dan evaluasi yang membosankan; (5) pengajaran selalu dipakai sebagai masukan untuk dilakukan dengan menggunakan $C D$ melakukan refleksi atas apa yang pembelajaran; (6) Nilai prestasi hasil terjadi pada tahap pelaksanaan. Hasil belajar fisika masih sangat rendah dari proses refleksi ini kemudian dengan rata-rata 4,35; (7) daya serap melandasi upaya perbaikan dan menangkap pelajaran setiap siswa penyempurnaan rencana tindakan sangat bervariasi ada yang cepat, berikutnya. Tahapan-tahapan di atas sedang dan lambat; (8) pentingnya dilakukan berulang-ulang dan memotivasi anak didik untuk tertarik berkesinambungan sampai suatu dan dapat berinteraksi dengan pelajaran kualitas keberhasilan tertentu dapat yang diajarkan. PTK ini bertujuan agar tercapai (Aqib, 2008).

Dalam hubungannya dengan guru fisika (1) mengetahui motivasi proses belajar mengajar sangat penting siswa terhadap pelajaran fisika yang diajar menggunakan pembelajaran guru dapat memotivasi siswa untuk NHT; (2) mengetahui prestasi hasil tertarik dan berinteraksi dengan belajar siswa yang diajar menggunakan pelajaran yang diajarkan. Memberikan pembelajaran NHT.

motivasi kepada siswa berarti Cooperative learning tipe numbered menggerakkan siswa untuk melakukan heads together (NHT) sesuatu atau ingin melakukan sesuatu. Pembelajaran kooperatif Berdasarkan uraian di atas dapat (cooperative learning) merupakan 
Dandan. L. S, Ishafit.- Penggunaan Cooperative Learning...

strategi pembelajaran yang meng- salah satu nomor anggota untuk utamakan adanya kerjasama antar mempresentasikan hasil kerja siswa dalam kelompok untuk mencapai kelompoknya. Kelebihan yang dimiliki tujuan pembelajaran. Siswa dibagi oleh NHT ini adalah setiap siswa kedalam kelompok-kelompok kecil dan menjadi siap semua, dapat melakukan diarahkan untuk mempelajari materi diskusi dengan sungguh-sungguh, dan pelajaran yang telah ditentukan. Tujuan siswa yang pandai dapat mengajari dibentuknya kelompok kooperatif siswa yang kurang pandai. Sedangkan adalah untuk memberikan kesempatan kelemahan NHT ini adalah kepada siswa agar dapat terlibat secara kemungkinan nomor yang dipanggil, aktif dalam proses berpikir dan dalam dipanggil lagi oleh guru dan tidak kegiatan-kegiatan belajar. Dalam hal ini sebagian besar aktifitas pembelajaran berpusat pada siswa, yakni mempelajari materi pelajaran serta berdiskusi untuk memecahkan masalah (Latief, 2009).

Lie (2008) dalam bukunya yang berjudul coperative learning mengungkapkan teknik belajar NHT dikembangkan oleh Spencer Kagan tahun 1992. Teknik ini merupakan salah satu tipe dalam cooperative learning yang memberikan kesempatan kepada siswa untuk saling membagikan ide-ide dan mempertimbangkan jawaban yang paling tepat. Model NHT terdiri 4 langkah utama yaitu penomoran, guru mengajukan permasalahan, berpikir bersama (diskusi kelompok) dan guru menyebutkan semua anggota kelompok dipanggil oleh guru (Wijaya \& Dwitagama, 2008).

\section{Motivasi belajar}

Uno (2008) mengatakan bahwa istilah motivasi berasal dari kata motif yang berarti kekuatan yang terdapat dalam diri individu yang menyebabkan individu itu berbuat atau bertindak. Menurut Sardiman motivasi adalah serangkaian usaha untuk menyediakan kondisi tertentu sehingga seseorang mau dan ingin melakukan sesuatu (Riduan, 2008). Susilo (2006) menyatakan bahwa motivasi adalah dorongan yang menyebabkan terjadi suatu perbuatan atau tindakan tertentu. Dapat disimpulkan motivasi adalah segala sesuatu yang membuat seseorang terdorong untuk melakukan 
sesuatu. Motivasi mengandung tiga menarik dalam belajar; (6) adanya komponen pokok, yaitu: (1) lingkungan belajr yang kondusif, menggerakkan yang berarti menimbul- sehingga memungkinkan seseorang kan kekuatan kepada individu untuk siswa dapat belajar dengan baik (Uno, memimpin dan bertindak dengan cara 2008). Sardiman (2007) mengatakan tertentu (2) mengarahkan atau tujuan belajar itu ada tiga jenis yaitu menyalurkan tingkah laku (3) (1) untuk mendapatkan pengetahuan; menopang tingkah laku (Purwanto, (2) penanaman konsep dan 2004).

keterampilan; dan (3) pembentukan

Motivasi dan belajar merupakan dua hal yang saling mempengaruhi. Adanya motivasi yang baik dalam belajar akan menunjukkan hasil yang baik. Dengan kata lain, dengan adanya usaha yang tekun dan terutama didasari adanya motivasi, maka siswa yang belajar akan melahirkan prestasi yang baik (Sardiman, 2007). Menurut Dimyati dan Mudjiono (2002) balajar merupakan proses melibatkan manusia secara orang per orang sebagai satu kesatuan organisme sehingga terjadi perubahan pada pengetahuan, keterampilan dan sikap. Indikator motivasi belajar dapat diklasifikasikan sebagai berikut: (1) adanya hasrat dan keinginan untuk berhasil; (2) adanya dorongan dan kebutuhan dalam belajar; (3) adanya harapan dan cita-cita masa depan; (4) adanya penghargaan dalam belajar; (5) adanya kegiatan yang sikap.

\section{Prestasi belajar fisika}

Prestasi belajar berasal dari kata prestasi dan belajar. Prestasi diartikan sebagai hasil yang telah dicapai dari apa yang telah dilakukan atau dikerjakan. Prestasi belajar adalah penguasaan pengetahuan atau keterampilan yang dikembangkan oleh mata pelajaran lazimnya ditunjukkan dengan nilai tes angka nilai yang diberikan oleh guru, dan prestasi akademik mempunyai pengertian sebagai hasil pelajaran yang diperoleh dari kegiatan persekolahan yang bersifat kognitif dan biasaanya ditentukan melalui pengukuran dan penilaian (Depdikbud,1988).

\section{METODE}

Subjek pelaku tindakan yaitu peneliti yang sekaligus sebagai 
Dandan. L. S, Ishafit.- Penggunaan Cooperative Learning...

pengajar. Subjek penerima tindakan adalah 40 siswa kelas VIIIA semester 2. Penelitian ini dilaksanakan di SMP Muhammadiyah 9 Yogyakarta. Setting penelitian yang digunakan pada penelitian ini adalah setting kelas dan kelompok dalam pembelajaran fisika dimana siswa dikelompokkan menjadi 8 kelompok dan setiap kelompok terdiri atas 5 siswa. Pembagian kelompok diskusi berdasarkan hasil tes mid semester 2 kelas VIIIA. Jenis Penelitian ini adalah Penelitian Tindakan Kelas (PTK) atau Classroom Action Research (CAR). PTK ini dilakukan secara kolaboratif dan partisipatif.

Dalam penelitian ini instrumen yang digunakan berupa Rencana Pelaksaan Pembelajaran (RPP), tugas diskusi kelompok, tes soal prestasi hasil belajar fisika serta angket motivasi belajar siswa. Adapun tahaptahap dari suatu siklus dalam penelitian tindakan kelas dapat dijelaskan sebagai berikut: (1) Siklus I (a) Perencanaan, pada tahap ini peneliti merancang tindakan yang akan dilakukan dalam penelitian, diantaranya: melakukan pengamatan mengenai kondisi sekolah, kondisi kelas, kondisi siswa, sarana dan prasarana yang mendukung pembelajaran dan model yang digunakan dalam pembelajaran, membuat angket motivasi siswa, menyusun RPP, tugas kelompok, tes uji pendahuluan, dan tes prestasi siklus I (b) Pelaksanaan, pada pertemuan I hal yang dilakukan adalah menyampaikan tujuan dan capaian pembelajaran, membagi siswa menjadi 8 kelompok, tiap kelompok terdiri dari 5 orang, membagi lembar permasalahan kepada setiap kelompok, setiap orang dalam kelompok memilih satu permasalahan, menjelaskan NHT, menyiapkan perwakilan kelompok yang akan mempresentasikan masalah, membimbing presentasi, guru sebagai moderator, siswa menjadi lebih aktif. Pertemuan II, melanjutkan presentasi kelompok sampai dengan selesai. Pertemuan III, guru mengingatkan kembali pelajaran terdahulu dengan pertanyaan ringan, memberikan tes tertulis siklus I (c) observasi, yaitu ketika pembelajaran dilaksanakan, peneliti melakukan pengamatan dan pencatatan terhadap aktivitas siswa dan semua hambatan yang terjadi di kelas (d) refleksi yaitu pembelajaran pada siklus I dianalisis untuk dilakukan perbaikan yang diterapkan pada siklus 
berikutnya. Analisis dilakukan pada tes prestasi hasil belajar siswa; (2) Siklus II (a) Perencanaan, pada tahap ini hal yang dilakukan peneliti membuat skenario pembelajaran yang lebih baik dan mampu mengatasi kekurangan pada pembelajaran siklus I, dalam hal ini siswa meminta penjelasan latihan soal dan meminta ringkasan materi yang akan disampaikan. Hal ini dikarenakan masih terdapat siswa yang tidak memiliki buku pelajaran. Kemudian menyusun instrumen pembelajaran dilanjutkan dengan menyusun alat evaluasi setiap akhir pembelajaran untuk melihat hasil belajar siswa (b) Pelaksanaan pada pertemuan I, menyampaikan hasil evaluasi pembelajaran pada siklus I, dan menjelaskan hal-hal yang perlu dilakukan oleh siswa untuk meningkatkan hasil belajar, melakukan diskusi singkat dengan siswa untuk perbaikan pembelajaran sebelumnya, membagikan ringkasan materi dan menjelaskan latihan soal. Pertemuan II, membagi siswa menjadi 8 kelompok, tiap kelompok terdiri dari 5 orang, membagi lembar permasalahan kepada setiap kelompok, setiap orang dalam kelompok memilih satu permasalahan, menjelaskan metode NHT menyiapkan perwakilan kelompok yang akan mempresentasikan masalah, membimbing presentasi, guru sebagai moderator, siswa menjadi lebih aktif. Pertemuan III, mengingatkan kembali pelajaran terdahulu dengan pertanyaan ringan, memberikan tes tertulis siklus 2 (c) Observasi, ketika pembelajaran dilaksanakan, peneliti melakukan pengamatan dan pencatatan terhadap aktivitas siswa dan semua hambatan yang terjadi di kelas (d) refleksi yakni menganalisis dan mengolah data yang diperoleh selama kegiatan berlangsung. Hasil analisa pada siklus II dibandingkan dengan hasil analisis pada siklus I untuk mengetahui peningkatan prestasi hasil belajar siswa terhadap materi pembelajaran.

Gambar1. Skema Pelaksanaan Tindakan

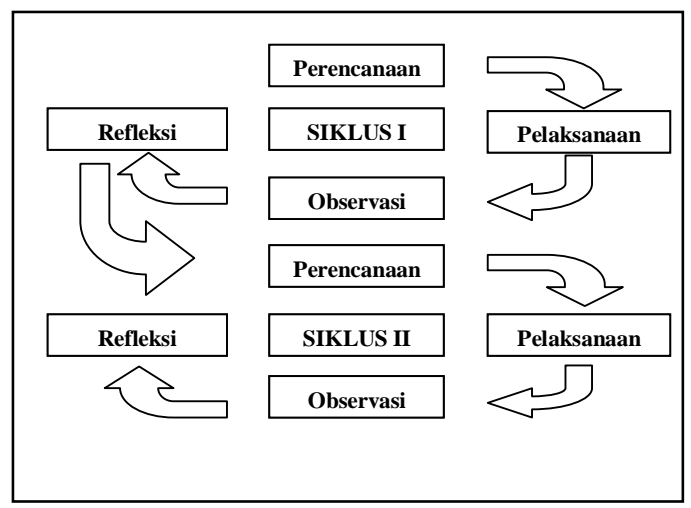


Dandan. L. S, Ishafit.- Penggunaan Cooperative Learning...

\section{Teknik Pengumpulan Data}

Observasi kelas digunakan untuk memperoleh data tentang kegiatan siswa dan kegiatan guru salama berlangsungnya proses pembelajaran fisika sebelum diterapkannya model cooperative learning tipe NHT. Angket yang digunakan untuk mengetahui motivasi siswa adalah angket tertutup. Jumlah item soal angket motivasi belajar adalah 15 butir soal. Angket ini diberikan disetiap akhir siklus. Berikut ini adalah kisi-kisi angket motivasi belajar siswa:

Tabel 1.

Kisi-Kisi Angket Motivasi Belajar Siswa

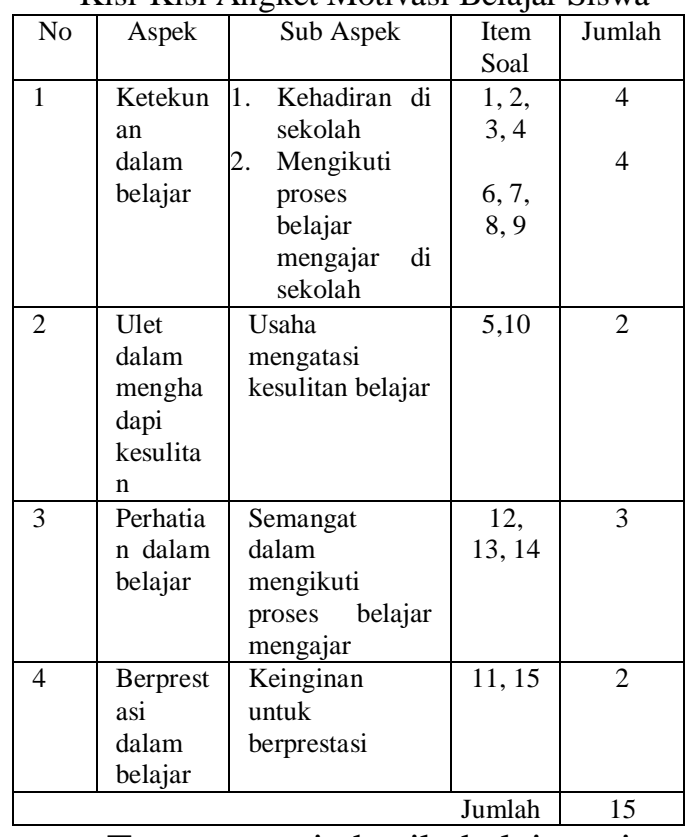

Tes prestasi hasil belajar siswa dilakukan pada setiap akhir siklus untuk mengetahui perubahan yang terjadi pada proses pembelajaran fisika. Pada siklus I dan siklus II tes prestasi hasil belajar menggunakan soal pilihan ganda dengan soal sebanyak 20 butir soal untuk siklus I dan 15 butir soal untuk siklus II.

Analisis data dalam penelitian ini menggunakan metode deskriptif kualitatif. Data yang diperoleh dari hasil observasi sebelum tindakan dilakukan, jawaban tes prestasi hasil belajar fisika dan angket yang berisi tentang motivasi siswa. Hasil observasi digunakan sebagai latar belakang masalah penelitian tindakan ini. Peningkatan prestasi siswa dapat dilihat dari hasil perbandingan rata-rata nilai tes prestasi hasil belajar fisika setiap siklus. Analisis tes prestasi hasil belajar fisika setiap siklus bertujuan untuk mendeskripsikan prestasi belajar fisika siswa digunakan kriteria ketuntasan belajar.

Komponen-komponen yang menjadi indikator keberhasilan peneliti ini adalah tercapainya peningkatan prestasi belajar fisika dengan menggunakan model NHT diantaranya : (1) motivasi, siswa mempunyai semangat yang sangat baik dalam mengikuti pembelajaran, selalu memperhatikan selama proses pembelajaran berlangsung, selalu merespon setiap 
pertanyaan yang diberikan peneliti, serta tidak gaduh selama pembelajaran berlangsung; (2) penguasaan materi, berdasarkan kriteria ketuntasan minimal (KKM) yang digunakan di SMP ini adalah 6,5 maka siswa dikatakan tuntas jika pada tes prestasi hasil belajar fisika mendapatkan nilai minimal 6,5.

\section{HASIL DAN PEMBAHASAN}

Berdasarkan observasi yang dilakukan didapatkan hasil bahwa siswa kurang tertarik untuk mengikuti pelajaran fisika karena proses pembelajaran yang membosankan karena kurang bervariasinya model pembelajaran yang digunakan yaitu menggunakan CD pembelajaran saja.

Proses pembelajaran dalam penelitian tindakan ini adalah

menggunakan model NHT yang terdiri 4 langkah utama yaitu penomoran, guru mengajukan permasalahan, berpikir bersama (diskusi kelompok) dan guru menyebutkan salah satu nomor anggota untuk mempresentasikan hasil kerja kelompoknya. Dalam penentuan kelompok peneliti menggunakan hasil ujian tengah semester 2 sehingga dalam setiap kelompok terdiri atas siswa yang mempunyai tingkat kemampuan yang beragam, ada yang pintar, sedang, dan ada pula yang tingkat kemampuannya kurang. Sebelum diskusi kelompok dilakukan terlebih dahulu dilaksanakan demonstrasi pembuatan bentuk-bentuk lensa.

Hasil penelitian dapat diihat di tabel 2 dan tabel 3.

Tabel 2. Hasil Tes Belajar Siswa

\begin{tabular}{|c|c|c|c|c|c|c|}
\hline & \multicolumn{3}{|c|}{ Siklus I } & \multicolumn{3}{c|}{ Siklus II } \\
\cline { 2 - 7 } & Terendah & Tertinggi & $\begin{array}{c}\text { Rata- } \\
\text { rata }\end{array}$ & Terendah & Tertinggi & $\begin{array}{c}\text { Rata- } \\
\text { rata }\end{array}$ \\
\hline Hasil belajar & 4,5 & 7,5 & 6,17 & 6,7 & 10 & 8,29 \\
\hline Ketuntasan & \multicolumn{3}{|c|}{$52,5 \%$} & \multicolumn{3}{c|}{$100 \%$} \\
\hline
\end{tabular}

Tabel 3. Hasil Motivasi Belajar Siswa

\begin{tabular}{|c|c|c|c|c|}
\hline \multirow{2}{*}{ Motivasi } & \multicolumn{2}{|c|}{ Siklus I } & \multicolumn{2}{c|}{ Siklus II } \\
\cline { 2 - 5 } & $\%$ & kategori & $\%$ & Kategori \\
\hline \multirow{2}{*}{ Individual } & 65 & Baik & 80 & Sangat Baik \\
\cline { 2 - 5 } & 35 & Kurang & 20 & Baik \\
\hline Klasikal & 66,3 & Baik & 95 & Sangat Baik \\
\hline
\end{tabular}


Dandan. L. S, Ishafit.- Penggunaan Cooperative Learning ...

Penelitian ini dilaksanakan kan, peneliti melakukan pengamatan sebanyak 2 siklus yang masing-masing dan pencatatan terhadap aktivitas siswa siklus terdiri atas perencanaan, dan semua hambatan yang terjadi di pelaksanaan, observasi dan refleksi. kelas. Tahapan terakhir pada siklus I Pada siklus I hal-hal yang dilakukan yaitu refleksi.

meliputi perencanaan, pada tahap ini peneliti merancang tindakan yang akan dilakukan dalam penelitian, diantaranya: melakukan observasi sekolah, observasi kelas dan membuat perangkat pembelajaran. Pelaksanaan, pada pertemuan I hal yang dilakukan adalah menyampaikan tujuan dan capaian pembelajaran, melakukan demonstrasi, membagi siswa menjadi 8 kelompok, tiap kelompok terdiri dari 5 orang, yang baik. Hasil yang didapatkan membagi lembar soal kepada setiap adalah siswa mengajukan agar kelompok, setiap orang dalam dilakukan pembahasan latihan soal kelompok memilih satu permasalahan, mengenai penerapan rumus dan menjelaskan model NHT, menyiapkan pembagian ringkasan materi yang akan perwakilan kelompok yang akan dipelajari karena masih terdapat siswa mempresentasikan masalah, mem- yang belum memiliki buku pelajaran.

bimbing presentasi, guru sebagai Pada siklus II tahapan yang moderator, siswa menjadi lebih aktif. dilakukan meliputi perencanaan, pada Pertemuan II, melanjutkan presentasi tahap ini hal yang dilakukan peneliti kelompok sampai dengan selesai. membuat skenario pembelajaran yang Pertemuan III, guru mengingatkan lebih baik dan mampu mengatasi kembali pelajaran terdahulu dengan kekurangan pada pembelajaran siklus I, pertanyaan ringan, memberikan tes dalam hal ini siswa meminta penjelasan tertulis siklus I. Ketiga yaitu observasi, latihan soal dan meminta ringkasan yaitu ketika pembelajaran dilaksana- materi yang akan disampaikan. Hal ini 
Dandan. L. S, Ishafit.- Penggunaan Cooperative Learning...

dikarenakan masih terdapat siswa yang tidak memiliki buku pelajaran. Kemudian menyusun instrumen pembe-lajaran dilanjutkan dengan menyusun alat evaluasi setiap akhir pembelajaran untuk melihat hasil belajar siswa. Tahap kedua pelaksanaan, pada pertemuan I, menyampaikan hasil evaluasi pembelajaran pada siklus I, dan menjelaskan hal-hal yang perlu dilakukan oleh siswa untuk meningkatkan hasil belajar, melakukan diskusi singkat dengan siswa untuk perbaikan pembelajaran sebelumnya, melaksanakan demonstrasi, membagikan ringkasan materi dan menjelaskan latihan soal. Pertemuan II, membagi siswa menjadi 8 kelompok, tiap kelompok terdiri dari 5 orang, membagi lembar permasalahan kepada setiap kelompok, setiap orang dalam kelompok memilih satu permasalahan, menjelaskan metode NHT, menyiapkan perwakilan kelompok yang akan mempresentasikan masalah, membimbing presentasi, guru sebagai moderator, siswa menjadi lebih aktif. Pertemuan III, mengingatkan kembali pelajaran terdahulu dengan pertanyaan ringan, memberikan tes tertulis siklus
2. Tahap ketiga yaitu Observasi, ketika pembelajaran dilaksana-kan, peneliti melakukan pengamatan dan pencatatan terhadap aktivitas siswa dan semua hambatan yang terjadi di kelas. Tahap keempat refleksi yakni menganalisis dan mengolah data yang diperoleh selama kegiatan berlangsung.

Hasil analisis pada siklus II dibandingkan dengan hasil analisis pada siklus I untuk mengetahui peningkatan prestasi hasil belajar siswa terhadap materi pembelajaran. Hasil yang diperoleh dari siklus I adalah sebanyak 21 siswa sekitar 52,5\% dinyatakan lulus atau tuntas dengan rata-rata kelas sebesar 6,17 sedangkan nilai terendah terdapat nilai 4,5 dan nilai tertinggi terdapat nilai 7,5. Acuan ketuntasan belajar tersebut berdasarkan nilai tes prestasi hasil belajar fisika pada siklus I telah sesuai dengan kriteria ketuntasan minimum (KKM) yaitu 6,5 untuk mata pelajaran fisika. Kemudian setelah dilaksanakan siklus II tes prestasi hasil belajar mengalami peningkatan yang signifikan yaitu nilai rata-rata kelas menjadi 8,29 dengan persentase ketuntasan klasikal sebesar $100 \%$ dengan nilai terendah 6,7 dan nilai tertinggi 10 . Berdasarkan hasil 
Dandan. L. S, Ishafit.- Penggunaan Cooperative Learning...

yang didapat pada siklus II maka penelitian ini dapat dinyatakan telah selesai.

Hasil angket motivasi belajar yang diberikan pada setiap akhir siklus pembelajaran yang diperoleh pada siklus I adalah $65 \%$ siswa termasuk dalam kategori baik motivasi belajarnya, 35\% siswa masuk dalam kategori kurang motivasi belajarnya dan secara klasikal motivasi belajar siswa adalah sebesar 66,3\%. Sedangkan pada siklus II $80 \%$ siswa termasuk dalam kategori sangat baik motivasi belajarnya dan $20 \%$ siswa termasuk dalam kategori baik motivasinya dan secara klasikal sebanyak 95\% siswa telah memiliki motivasi belajar yang sangat baik dalam belajar fisika dengan model pembelajaran yang digunakan.

Dengan acuan hasil angket motivasi belajar fisika dan hasil prestasi hasil belajar siswa maka hipotesis penelitian ini dapat diterima yaitu dengan menggunakan NHT maka motivasi dan prestasi hasil belajar fisika kelas VIII di SMP Muhammdiyah 9 Yogyakarta dapat ditingkatkan dengan menerapkan metode demonstrasi.

\section{PENUTUP}

\section{Kesimpulan}

Berdasarkan hasil penelitian dapat ditarik kesimpulan bahwa motivasi dan prestasi hasil belajar fisika dapat ditingkatkan dengan menggunakan NHT dengan menerapakan metode demonstrasi pada siswa kelas VIIIA SMP Muhammadiyah 9 Yogyakarta.

\section{Saran}

Berdasarkan hasil kesimpulan penelitian, maka penulis mengajukan saran sebagai berikut : (1) Penggunaan NHT sebagai alternatif model pembelajaran fisika agar siswa tidak merasa bosan dan menjadi tertarik untuk mengikuti pelajaran fisika; (2) Berdasarkan hasil penelitian yang telah dilakukan ternyata pembelajaran menggunakan NHT dengan menerapkan metode demonstrasi memperoleh hasil yang jauh lebih baik, maka sebaiknya diupayakan dalam penyusunan instrumen lebih baik lagi untuk menunjang keberhasilan dalam meningkatkan prestasi belajar fisika siswa.

\section{DAFTAR PUSTAKA}

Arikunto, Suharsimi, Suhardjono, \& Supardi. 2009. Penelitian 
Dandan. L. S, Ishafit.- Penggunaan Cooperative Learning...

Tindakan Kelas. Jakarta: Bumi Aksara.

Aqib, Zaenal. 2008. Penelitian Tindakan Kelas untuk Guru. Bandung: Yrama Widya.

Depdikbud. 1988. Kamus Besar Bahasa Indonesia. Jakarta: Balai Pustaka.

Dimyati dan Mudjiono. 2002. Belajar dan Pembelajaran. Jakarta: Rineka Cipta.

Latief, Nurwahyuni. 2009. Model Pembelajaran Kooperatife Tipe NHT. $\quad$ http://pendidikanmatematika.blogspot.com/2009/03/ contoh-skripsi-modelpembelajaran.html

Lie. Anita. 2008. Cooperative Learning (Mempraktekkan Cooperative Learning di Ruang-ruang Kelas). Jakarta: PT Grasindo.

Purwanto, M Ngalim. 2004. Psikologi Pendidikan. Bandung: Remaja Rosdakarya.

Riduwan. 2008. Belajar Mudah Penelitian untuk Guru-Karyawan dan Peneliti Pemula. Bandung: Alfabeta.

Sardiman. 2007. Interaksi dan Motivasi Belajar Mengajar. Jakarta: Rajawali Pers.

Supriyadi. 2007. Kurikulum Sains dalam Proses Pembelajaran Sains. Yogyakarta: Pustaka Tempel Sari.

Susilo. 2006. Kurikulum Tingkat satuan Pendidikan (Manajemen Pelaksanaan dan Kesiapan Sekolah). Yogyakarta: Pustaka Pelajar.

Susilo, Muhammad Joko. 2006. Bekal Bagi Calon Guru Belajar dan Mengajar. Yogyakarta: Universitas Ahmad Dahlan.

Uno, Hamzah B. 2008. Teori Motivasi dan Pengukurannya, Analisis di
Bidang Pendidikan. Jakarta: PT Bumi Aksara.

Wijaya \& Dwitagama, Kusuma dan Dedi Dwitagama. 2009. Mengenal Penelitian Tindakan Kelas. Jakarta: PT Indeks. 